\title{
Testicular Function in Klinefelter Syndrome
}

\author{
Anne M. Wikström Leo Dunkel \\ Hospital for Children and Adolescents, Helsinki University Central Hospital, University of Helsinki, Helsinki, and \\ Department of Pediatrics, Kuopio University Hospital, University of Kuopio, Kuopio, Finland
}

\section{Key Words}

Klinefelter syndrome $\cdot 47, \mathrm{XXY} \cdot$ Testicular degeneration •

Testicular histology and testicular function

\begin{abstract}
Klinefelter syndrome (KS) is the most common genetic form of male hypogonadism, but the phenotype becomes evident only after puberty. During childhood, and even during early puberty, pituitary-gonadal function in 47,XXY subjects is relatively normal, but from midpuberty onwards, FSH and $\mathrm{LH}$ levels increase to hypergonadotropic levels, inhibin B decreases to undetectable levels, and testosterone after an initial increase levels off at a low or low-normal level. Hence, most adult KS males display a clear hypergonadotropism with a varying degree of androgen deficiency; subsequently, testosterone substitution therapy is widely used to prevent symptoms and sequels of androgen deficiency. Testicular biopsies of prepubertal KS boys have shown preservation of seminiferous tubules with reduced numbers of germ cells, but Sertoli and Leydig cells have appeared normal. The testes in the adult KS male are, however, characterized by extensive fibrosis and hyalinization of the seminiferous tubules, and hyperplasia of the interstitium, but the tubules may show residual foci of spermatogenesis. Introduction of testicular sperm extraction in combination with intracytoplasmic sperm injection techniques has allowed non-mosaic KS males to father children.

Copyright $\odot 2008$ S. Karger AG, Basel
\end{abstract}

\section{KARGER}

Fax +4161306 1234 E-Mail karger@karger.ch www.karger.com
(C) 2008 S. Karger AG, Basel

0301-0163/08/0696-0317\$24.50/0

Accessible online at:

www.karger.com/hre

\section{Introduction}

Klinefelter syndrome (KS) was first described by Harry F. Klinefelter [1] in 1942 as a clinical entity characterized by gynecomastia, small testes, absent spermatogenesis, normal to moderately reduced Leydig cell function, and increased secretion of FSH. The disorder was in 1959 found to be caused by a supernumerary X chromosome [2]. Today, studies indicate that some $80 \%$ of KS males have the karyotype $47, \mathrm{XXY}$, and $20 \%$ higher-grade chromosome aneuploidies, 46,XY/47,XXY mosaicism, or structurally abnormal X chromosomes [3]. With an estimated prevalence of about 1 in 600 newborn males, KS is the most common sex chromosome abnormality [4]. It is among the most frequent genetic causes of human infertility, occurring in $11 \%$ of azoospermic men and $4 \%$ of infertile men [5]. The classical phenotype of KS is widely recognized, but many affected subjects present only very discrete symptoms. Consequently, the disorder is underdiagnosed; only approximately a fourth of adult males with KS receive diagnoses, and fewer than $10 \%$ of the expected number are diagnosed before puberty $[4,6]$.

Many of the clinical findings in KS may be attributed to the hypogonadism typical for this syndrome, but some are instead caused directly by the chromosome abnormality. KS is diagnosed prenatally by routine amniocentesis quite rarely, because the association with advanced maternal age is weak $[3,7]$, and at birth most 47,XXY neonates appear normal $[8,9]$. During childhood, the KS

Anne Wikström, $\mathrm{MD}, \mathrm{PhD}$

HUCH, Hospital for Children and Adolescents

University of Helsinki, PO Box 281

FI-00029 Helsinki (Finland)

Tel. +358 9471 75293, Fax +3589471 75888, E-Mail anne.wikstrom@fimnet.fi 
Table 1. Follow-up of 14 adolescent boys with KS

\begin{tabular}{|c|c|c|c|c|c|c|}
\hline & \multicolumn{6}{|l|}{ Age, years } \\
\hline & $10-11$ & $11-12$ & $12-13$ & $13-14$ & $14-15$ & $15-16$ \\
\hline Tanner P-stage* & $1(9)$ & $1,1-2(9)$ & $2,1-3(13)$ & $2.5,1-4(11)$ & $3,1-4(9)$ & $4,3-5(4)$ \\
\hline Tanner G-stage* & $1(9)$ & $1,1-2(9)$ & $2,1-4(13)$ & $3.5,2-4(11)$ & $4,2-5(9)$ & $4,3-5(4)$ \\
\hline Mean testicular volume, $\mathrm{ml}$ & $1.1 \pm 0.5(5)$ & $1.8 \pm 0.9(9)$ & $2.1 \pm 0.5(12)$ & $2.9 \pm 0.5(11)$ & $2.6 \pm 0.7(9)$ & $2.4 \pm 1.2(4)$ \\
\hline Bone age, years & $9.5 \pm 2.1(4)$ & $11.0 \pm 1.2(7)$ & $12.3 \pm 1.1(9)$ & $13.1 \pm 1.0(11)$ & $13.8 \pm 0.8(7)$ & $15.0 \pm 0.7(2)$ \\
\hline $\mathrm{BMI}, \mathrm{kg} / \mathrm{m}^{2}$ & $17.7 \pm 2.2(8)$ & $19.3 \pm 2.7(10)$ & $19.3 \pm 2.9(13)$ & $19.7 \pm 2.4(11)$ & $19.7 \pm 3.1(9)$ & $18.9 \pm 2.0(4)$ \\
\hline Testosterone, nmol/l & $0.53 \pm 0.43$ & $0.78 \pm 0.37(9)$ & $2.81 \pm 2.68(7)$ & $5.65 \pm 4.50(7)$ & $7.60 \pm 3.62(6)$ & \\
\hline Estradiol, pmol/l & $10.9 \pm 3.1(3)$ & $11.6 \pm 5.5(5)$ & $16.4 \pm 4.8(6)$ & $26.4 \pm 16.5(4)$ & $32.5 \pm 10.7(4)$ & \\
\hline SHBG, nmol/l & $94 \pm 46(4)$ & $80 \pm 37(8)$ & $77 \pm 44(10)$ & $52 \pm 19(11)$ & $46 \pm 13(7)$ & $31 \pm 8(2)$ \\
\hline PSA, $\mu \mathrm{g} / \mathrm{l}$ & $0.024 \pm 0.022(4)$ & $0.038 \pm 0.042(9)$ & $0.077 \pm 0.058(7)$ & $0.216 \pm 0.184(7)$ & $0.369 \pm 0.254(5)$ & \\
\hline Leptin, $\mu g / 1$ & $14.1 \pm 7.3(4)$ & $14.7 \pm 7.9(9)$ & $14.7 \pm 7.3(11)$ & $9.8 \pm 6.0(11)$ & $8.9 \pm 6.8(9)$ & $13.8 \pm 8.0(2)$ \\
\hline Basal LH, IU/l & $0.2 \pm 0.1(6)$ & $0.5 \pm 0.3(10)$ & $2.3 \pm 2.9(13)$ & $6.4 \pm 3.5(11)$ & $11.4 \pm 6.1(9)$ & $15.8 \pm 5.8(4)$ \\
\hline$\Delta \mathrm{LH}(\mathrm{IU} / \mathrm{l})$ after $\mathrm{GnRH}$ stimulation & $3.6 \pm 3.3(4)$ & $8.7 \pm 7.9(7)$ & $10.4 \pm 6.6(6)$ & $36.4 \pm 24.4(6)$ & $25.6 \pm 16.2(3)$ & \\
\hline Basal FSH, IU/l & $1.2 \pm 0.6(6)$ & $2.6 \pm 2.6(10)$ & $5.8 \pm 6.1(13)$ & $19.8 \pm 12.4(11)$ & $30.2 \pm 16.8(9)$ & $32.8 \pm 16.3(4)$ \\
\hline$\Delta \mathrm{FSH}(\mathrm{IU} / \mathrm{l})$ after GnRH stimulation & $2.3 \pm 1.0(4)$ & $3.5 \pm 3.5(7)$ & $2.1 \pm 1.5(6)$ & $13.9 \pm 11.7(6)$ & $9.2 \pm 7.5(3)$ & \\
\hline Inhibin $\mathrm{B}, \mathrm{pg} / \mathrm{ml}$ & $90 \pm 25(4)$ & $93 \pm 64(9)$ & $96 \pm 59(12)$ & $48 \pm 52(11)$ & $41 \pm 60(8)$ & $23(1)$ \\
\hline $\mathrm{AMH}, \mathrm{pmol} / \mathrm{l}$ & $558 \pm 151(4)$ & $817 \pm 843(9)$ & $605 \pm 342(7)$ & $238 \pm 305(6)$ & $101 \pm 125(5)$ & \\
\hline INSL3, ng/ml & $<0.05$ & $0.12 \pm 0.24(7)$ & $0.23 \pm 0.23(8)$ & $0.57 \pm 0.31(9)$ & $0.58 \pm 0.08(5)$ & $0.88(1)$ \\
\hline
\end{tabular}

Means \pm SD (number of patients) and ${ }^{*}$ median, range (n) are displayed [see 17-19]. PSA = Prostate-specific antigen; AMH = anti-müllerian hormone; INSL3 = insulin-like factor 3 .

boy often presents with language delay, learning disabilities or behavioral problems $[6,10]$. Consequently, child neurologists or child psychiatrists, who perform chromosome analysis, along with fragile $\mathrm{X}$ screening, make the diagnosis. The tall stature typical of KS result from a notable increase in height velocity between ages 5 and 8 years owing to a greater leg growth, but otherwise identifying any differences between KS boys and normal boys in physical appearance is very difficult [11]. Furthermore, neither magnitude nor timing of the pubertal growth spurt differs from that of normal boys [11-13]. Only after puberty do small, firm testes and variable symptoms of androgen deficiency characterize the KS males most often detected among patients with azoospermia visiting at infertility clinics [6].

The aims of this article are to review present knowledge on longitudinal changes from fetal life to adulthood in hormone levels reflecting testicular function, and on morphological degeneration of the testis in KS.

\section{Reproductive Hormone Levels during Development}

\section{Fetal Period}

When prenatal testosterone was investigated in amniotic fluid obtained at antenatal diagnosis between 16 and 20 weeks of gestation from $20 \mathrm{XXY}$ fetuses and from XY and XX controls of the same age [14], no significant difference was evident between the two male groups; both had significantly higher levels than the XX fetuses.

\section{Neonatal Period}

At birth there already may be some impairment of Leydig cell function. Cord blood testosterone was significantly lower in $247, \mathrm{XXY}$ infants and in $146, \mathrm{XY} / \mathrm{XXY}$ than in 3 control infants [15]. However, in another study comparing testosterone levels of $6 \mathrm{KS}$ infants to levels in a large cohort of normal infants, no significant difference appeared [8]. Lahlou et al. [16] compared reproductive hormone levels during minipuberty in 18 prenatally diagnosed 47,XXY boys to those in 215 healthy boys. The KS infants' timing of peak serum testosterone was similar to healthy infants', but levels in the KS boys were significantly lower from birth to 8 months. However, their serum $\mathrm{LH}, \mathrm{FSH}$, inhibin $\mathrm{B}$ and anti-müllerian hormone $(\mathrm{AMH})$ levels were normal. Another study found, in 11 of $12 \mathrm{KS}$ boys under age 6 months, lower than normal serum testosterone levels but normal gonadotropin levels [9]. In contrast, Aksglaede et al. [17] found in $10 \mathrm{KS}$ infants aged 3.1 months, when compared to healthy controls, high normal concentrations of testosterone and elevated levels of LH and FSH. In summary, no indisputable hypoandrogenism appears in KS subjects during infancy. 


\section{Childhood and Adolescence}

Data from our own longitudinal follow-up study of 14 prepubertal and pubertal XXY boys are shown in table 1 [18-20]. Prepubertal 47,XXY boys are characterized by normal serum levels of testosterone, FSH, $\mathrm{LH}$, and inhibin B until onset of puberty [12, 18-23], and their serum testosterone responses to human chorionic gonadotropin stimulation are normal $[21,22]$. During puberty, after an initial normal adolescent increase, serum testosterone concentrations plateau and remain subsequently within the low-normal range throughout puberty $[18$, $20-22,24]$. Such testosterone levels seem sufficient to allow in KS boys normal onset and progression of puberty (fig. 1) and development of satisfactory secondary sexual characteristics $[11,18,21,22]$.

Insulin-like factor 3 (INSL3) is a peptide hormone secreted in a LH-dependent manner by fetal and fully differentiated Leydig cells [25-27]. It is only weakly expressed in immature prepubertal Leydig cells and in Leydig cells that have become hypertrophic or transformed [27]. Hence, INSL3 is suggested to be more sensitive than testosterone to Leydig cell dysfunction and differentiation status $[25,26]$. In healthy boys, puberty is associated with a marked increase in INSL3 levels that occurs concomitantly with significant increases in LH levels (fig. 2) $[20,28]$. In KS boys, no significant difference in comparison with healthy boys in INSL3 levels emerges in assessment by bone age or Tanner pubertal stages, but from midpuberty onwards, despite stimulation by high LH levels, a leveling off in INSL3 concentrations occurs (fig. 2) [20].

Serum estradiol $\left(\mathrm{E}_{2}\right)$ levels are already high in early pubertal 47,XXY boys and remain high, irrespective of the presence or absence of gynecomastia [12, 18, 21]. A tendency for higher $\mathrm{E}_{2}$ /testosterone ratios also occurs in pubertal KS boys, but their serum SHBG levels decrease normally [18].

Serum levels of inhibin B are considered to reflect Sertoli cell function during prepuberty and to become germ cell-dependent during midpuberty [29]. Onset of male puberty is normally associated with increasing serum concentration of inhibin $\mathrm{B}$, and already by pubertal stage 2 is the adult serum level of serum inhibin B reached [30, 31]. In patients with KS, inhibin B similarly showed progressive increase before the clinical onset of puberty, but this initial rise is followed by a rapid suppression accompanied by a simultaneous increase in serum testosterone $[19,23]$. Thus, a strong, inverse non-linear correlation appears in KS boys between serum inhibin B and testosterone levels [19]. In healthy subjects, serum concentrations

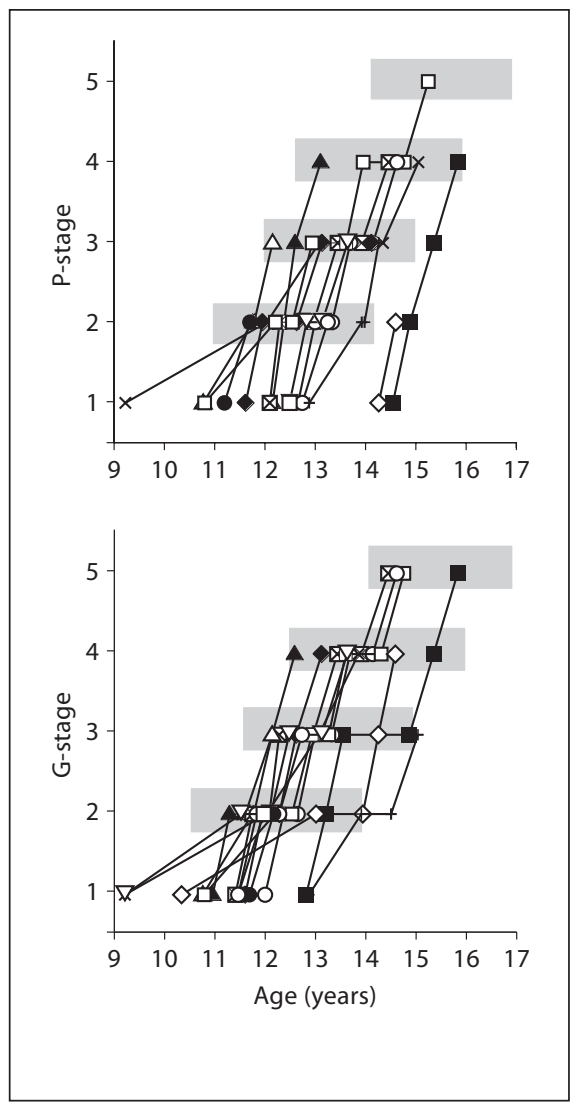

Fig. 1. Pubertal development in 14 boys with KS [for details, see 18]. Puberty staged according to Tanner. Shaded areas $=$ mean age \pm 2 SD for healthy Finnish boys [78].

of $\mathrm{AMH}$, another Sertoli cell marker, remain high throughout childhood and wane during normal male puberty concomitantly with rising testosterone levels and onset of meiosis in spermatogenesis [32-34]. Despite their lack of active spermatogenesis, in KS subjects this decrease in AMH levels also occurs $[16,19]$.

From midpuberty (at about age 13) onwards, KS subjects show a gradual increase in FSH and LH concentrations to hypergonadotropic levels, FSH levels increasing somewhat earlier and more markedly than do LH levels $[18,19,21,22,35]$. At the same time, the responses of both FSH and LH to gonadotropin-releasing hormone $(\mathrm{GnRH})$ stimulation become exaggerated $[18,21,22,36,37]$. These observations coincide with decreasing inhibin $\mathrm{B}$ and AMH levels, and leveling-offs in testosterone and INSL3 levels, and thus indicate a diminished testicular inhibition of gonadotropin secretion. 


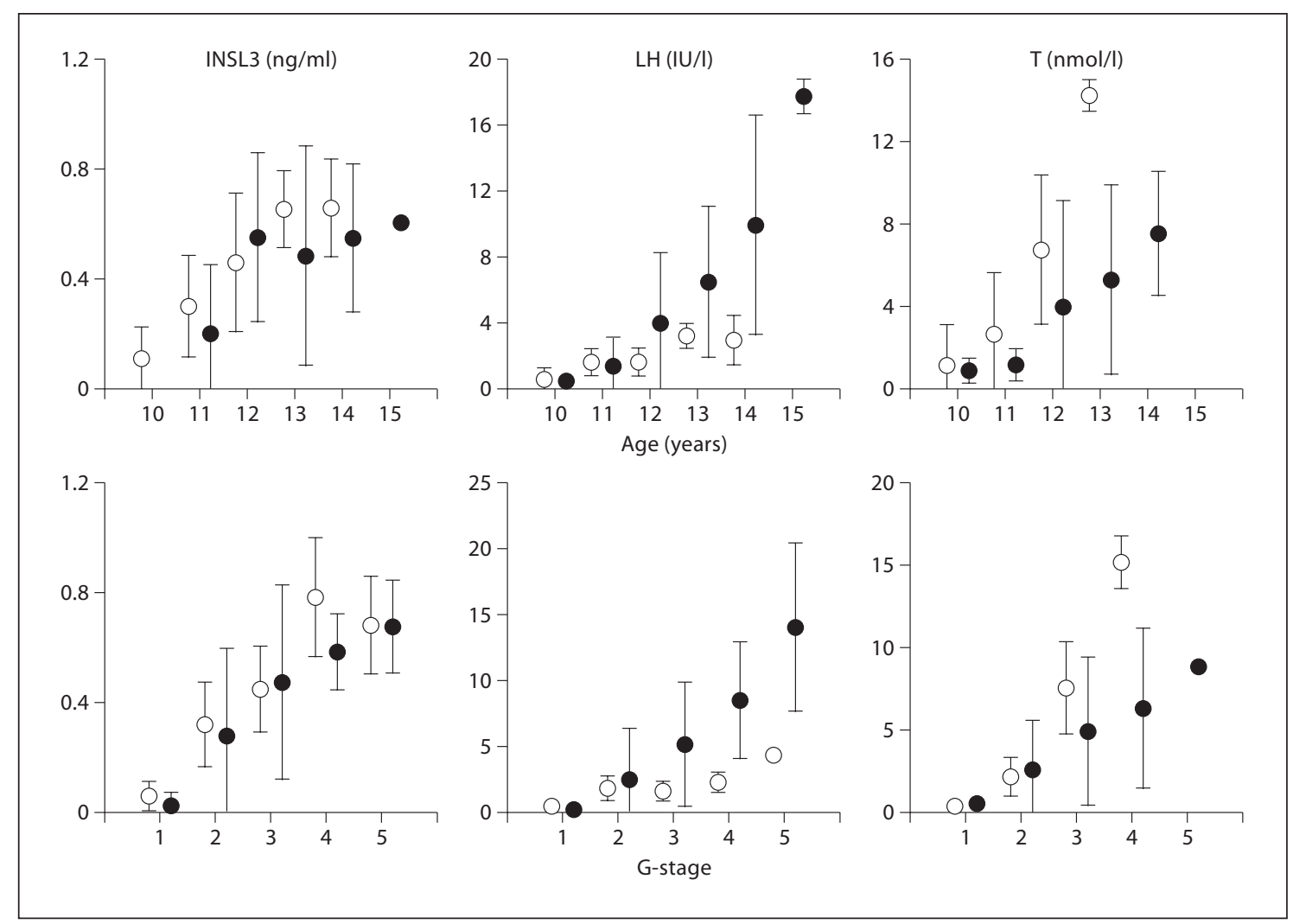

Fig. 2. Serum insulin-like factor 3 (INSL3), LH, and testosterone (T) levels during follow-up in 14 boys with KS (๑) compared to healthy boys $(\bigcirc)$ [for details, see 20]. Each by age (bone age according to the method by Greulich and Pyle [79]) or by G-stage (Tanner pubertal genital stage). Means \pm SD are shown.

\section{Adulthood}

Adult KS patients are characterized by hypergonadotropic hypogonadism. Concentrations of LH and FSH are high; FSH is usually higher, and little overlap occurs with normal individuals $[3,38]$. In $65-85 \%$ of adult KS patients, serum testosterone concentrations are below normal, but some may show levels within the normal range $[3,38]$. On average, serum concentrations of $E_{2}$ and $S H B G$ are higher than normal [3]. Serum inhibin B levels in most adult KS subjects are undetectable $[23,39,40]$, and recently it has been shown that adult KS patients have serum INSL3 concentrations significantly below normal $[25,26]$.

\section{Morphological Degeneration of the Testis}

\section{Fetal Period}

The degenerative process may start even during fetal life, as studies of aborted fetuses at gestational ages 18-22 weeks have shown $[41,42]$. A reduced number of germ cells and an increased proportion of tubules devoid of germ cells are visible in the testicular biopsies of midterm $47, \mathrm{XXY}$ fetuses, whereas the density and number of seminiferous tubules and mesenchymal structures appear normal [41]. Two authors have reported normal testicular histology in 47,XXY fetuses aborted at 17 and 20 weeks $[43,44]$.

\section{Neonatal Period}

Mikamo et al. [45] showed, over the first year of life, a progressive diminution in the number of spermatogonia from 24 to $0.1 \%$ of control value. The number and appearance of immature Sertoli cells appeared normal, as did interstitial tissue. In one 13-day-old 47,XXY infant, germ cells appeared in only $23 \%$ of seminiferous tubules, and the number of spermatogonia was reduced [46]. Numerous germ cells and immature Sertoli cells, and Leydig cells that appeared normal were evident in a testicular biopsy of a 4-week-old KS infant undergoing surgery for inguinal hernia [8], but a quantitative assay indicated a 

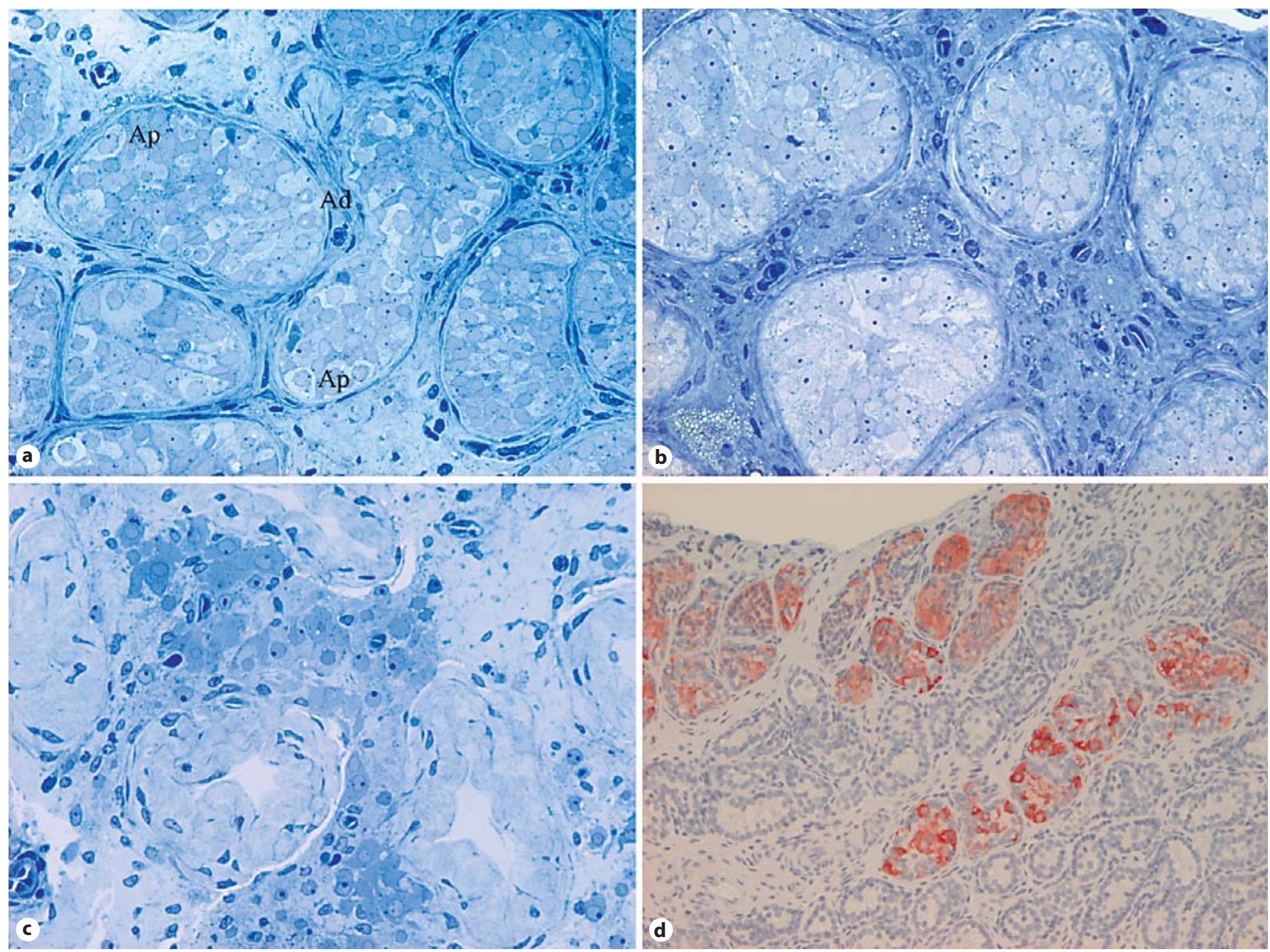

Fig. 3. Testicular biopsies of adolescent boys with KS displaying the progression of testicular degeneration during puberty. a KS boy, age 10.7 years, with spermatogonia. b 13.7-year-old with no spermatogonia. c 14-year-old with extensive degeneration. $\mathbf{d}$ The focal nature of the degeneration is obvious; seminiferous tubules with spermatogonia stained with MAGE-A4 surrounded by Sertoli-cell-only tubules in a 10-year-old patient. Ap = Pale adult spermatogonia; Ad = dark adult spermatogonia [for details, see 19, 50].

reduced number of spermatogonia. The 1-month-old 47,XXY infant in the group of KS boys studied by Müller et al. [47] showed a normal germ cell count in his biopsy despite bilateral undescended testes.

\section{Childhood and Adolescence}

Ferguson-Smith [48], reporting in 1959 on 8 mentally retarded prepubertal chromatin-positive KS boys, aged $7-12$, noted reduced size of the seminiferous tubules and a reduction in or complete absence of spermatogonia. A minority of the tubules were normal, containing a normal amount of spermatogonia; the majority were smaller tubules with undifferentiated Sertoli cells [48]. Müller et al. [47], studying testicular biopsies of $11 \mathrm{KS}$ boys between the neonatal period and 13 years of age, found no germ cells in their $9 \mathrm{KS}$ boys older than 2 years. It should, however, be noted in that study that all were cryptorchid [47], a condition which also reduces germ cell number [49].

In a study of 14 KS boys aged 10-14.0 years, histomorphometric and immunohistochemical analyses revealed that in early adolescence as many as 10 had germ cells in their testes $[19,50]$. The number of spermatogonia, especially adult dark spermatogonia, was however markedly 

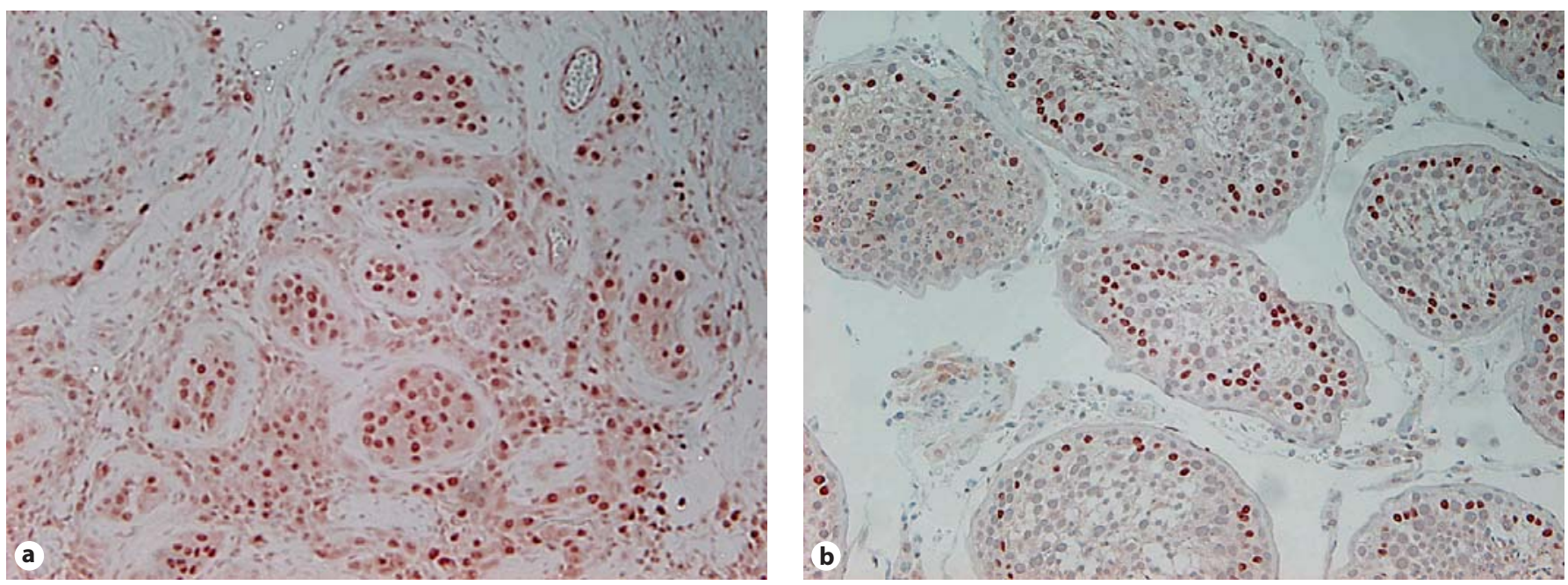

Fig. 4. Immunoexpression of the AR in testicular biopsies of (a) a 14-year-old boy with KS and (b) in a 16.5year-old healthy boy. Note the abundant expression of AR in Leydig cell cytoplasm in figure 4a [for details, see 50].

reduced, and the depletion of these cells accelerated with the activation of the pituitary-gonadal axis at the onset of puberty (fig. 3) [19, 50]. In prepubertal KS boys, the focal nature of the degeneration process is already evident, since the few seminiferous tubules containing spermatogonia are surrounded by Sertoli-cell-only tubules (fig. 3d). Germ cell differentiation is not delayed in KS boys; gonocytes mature into spermatogonia without significant delay, but a careful review of serial sections revealed no pachytene spermatocytes [50]. This indicates that in KS, germ cell differentiation is - at least partially - arrested at the spermatogonium or early primary spermatocyte stage. It seems that in KS, spermatogonia have difficulty entering meiosis; instead they proceed at onset of puberty to apoptosis.

In KS, immature Sertoli cells are incapable during puberty of transforming into the adult mature cell type [19]. Immunoexpression of inhibin $\alpha$-subunit indicates degeneration of the Sertoli cells, as also seen in electron microscopy of biopsies $[19,50]$. Inhibin B synthesis is obviously altered in subjects with KS, since both subunits are expressed in the Sertoli cells, even when serum inhibin B is unmeasurable [50]. With age, fibrosis and hyalinization of the interstitium and peritubular connective tissue increases, and already in 12- to 14-year-old KS boys, huge hyperplastic Leydig cells can be visible in testicular biopsies [19].

In normal males, androgen receptor (AR) expression first appears in Sertoli cell nuclei just before the onset of puberty but before final maturation of the Sertoli cells, concomitant with rising concentrations of FSH and testosterone [51]. In the absence of androgens, AR is located in the cytoplasm [52]. Our study revealed that the KS boys have, in contrast to age-matched controls, constant AR expression in their Sertoli cell cytoplasm (fig. 4) [50]. Furthermore, they have a smaller proportion of Sertoli cell nuclei expressing AR than do controls [50]. Our older KS boys showed a strong cytoplasmic AR staining of Leydig cells (fig. 4a), perhaps a sign of impaired function of hypertrophied Leydig cells, as also indicated by their high serum LH levels and a plateau in testosterone and INSL3 levels [18-20, 50].

In summary, these results characterizing the testicular degeneration process in the testes of adolescent KS boys confirm that this process accelerates at the onset of puberty.

\section{Adulthood}

Histology of the testes in the adult KS patient is characterized by extensive fibrosis and hyalinization of the seminiferous tubules, absence of spermatogenesis, and hyperplasia of Leydig cells and interstitium $[1,53]$. The patchy nature of the testicular histology, with more and less affected areas, has been described [54, 55]. The seminiferous tubules can be divided into two types according to Sertoli cell morphology, the first containing small immature Sertoli cells and the second type larger and more differentiated ones [56]. Later studies of the cytological features of these immature Sertoli cells have suggested a lower activity than that of mature Sertoli cells, probably 
resulting in impaired protein synthesis [57]. Regadera et al. [58] showed in their immunohistochemical and quantitative study that $78.9 \pm 9.1 \%$ of the Leydig cells were normal in their adult KS males compared to $96.0 \pm 10.0 \%$ in control men, and in KS that the functional activity of the Leydig cells was reduced.

\section{Genetic Mechanisms of Gonadal Failure}

Genetic features of the X chromosome appear to play a part in modulating KS phenotypes. The supernumerary $\mathrm{X}$ chromosome is paternal in $40-60 \%$ and maternal in $40-60 \%$ of KS cases $[3,7,59]$. In our study of 14 adolescent KS boys, the 3 subjects with an additional paternal $\mathrm{X}$ chromosome showed later onset and slower progression of puberty [60]. Other studies [61-63] have, however, suggested that parental origin of the extra $\mathrm{X}$ chromosome has no evident effect on the phenotypes of KS males. Data from several small patient series suggest that X chromosome isodisomy/heterodisomy and $\mathrm{X}$ chromosome inactivation pattern have no impact on the phenotype $[60,62$, 63], although these issues require study in detail in larger patient series.

The $A R$ gene on the $\mathrm{X}$ chromosome may play a particular role in differences in the KS phenotype. The $\mathrm{N}$ terminal domain of exon 1 of the $A R$ gene contains a highly polymorphic CAG repeat, the length of which is inversely associated with activity of the receptor [64]. A positive correlation exists with body height and presence of gynecomastia, but an inverse association with bone density, social status, testicular volume, and even with response to androgen substitution [65]. In another study, however, the only parameter associated with CAG repeat length was penile length; the correlation was inverse [63]. In addition, KS boys with a longer CAG repeat show later onset and slower progression of puberty and slower testicular degeneration process [60]. These findings are in agreement with diminished AR response to androgens when the $A R$ gene has a longer $C A G$ repeat.

Among genes on the $\mathrm{X}$ chromosome, a large number belong to the cancer testis antigen family and are expressed in testicular germs cells $[66,67]$. Mroz et al. [68] showed that $\mathrm{X}$ reactivation occurs during germ cell development in the XXY mouse, and it is assumed that for the survival of germ cells in the mature testis the proper $\mathrm{X}$ chromosome dose is crucial. Hence, molecular mechanisms induced by an altered dose of X-encoded genes in testicular cells may, during puberty, initiate the degeneration process in the testes of boys with KS.

Testicular Function in Klinefelter Syndrome

\section{Testosterone Substitution Therapy in KS}

When serum testosterone concentrations in KS patients become low, lifelong substitution therapy is indicated to prevent symptoms and consequences of androgen deficiency, and subsequently to improve quality of life. Beneficial effects of testosterone therapy in hypogonadal men have been demonstrated in several studies [3, 38].

KS subjects may benefit from testosterone supplementation during the first 2-3 months of life [7], although we still lack evaluation of the role of the minipuberty as a predictor of testicular insufficiency in KS. The KS boys have sufficient testosterone levels to allow normal onset and progression of puberty [11, 18, 21, 22], but development of a relative testosterone deficiency from midpuberty onwards is obvious. For instance, leveling out of INSL3 levels and exaggerated responses to GnRH stimulation indicate Leydig cell dysfunction $[18,20]$. This is also in agreement with histomorphometric and immunohistochemical analyses: Leydig cell hyperplasia and fibrosis of the interstitium develop with age, and immunoexpression of AR indicates diminished androgen action $[19,50]$. Consequently, although it seems that androgen supplementation in KS boys from midpuberty onwards is necessary, to date, placebo-controlled studies showing the benefits of early testosterone substitution are lacking, especially regarding the positive effects of early testosterone therapy on cognitive and behavioral parameters.

That the sperm retrieval rate appeared to be lower in KS men who previously received exogenous androgens may argue against the routine treatment of KS males with testosterone [69]. Actually, during spermatogenesis, testosterone causes a marked inhibition of spermatogonial maturation [70]. Concern for the maintenance of fertility potential in young KS men must be balanced against the potential benefits of testosterone replacement.

\section{Fertility in KS}

KS subjects are traditionally described as infertile. Semen analysis most often reveals azoospermia; in a cohort of $131 \mathrm{KS}$ males, only $8.4 \%$ had spermatozoa in their ejaculate [3]. Some spermatogonia in KS subjects are capable of completing the spermatogenic process leading to formation of mature spermatozoa, but with an increased risk for genetically imbalanced spermatozoa [71]. Consequently, because of the risk for producing a sex chromosomal abnormality in the offspring, most investigators

Horm Res 2008;69:317-326 
recommend professional genetic counseling and standard prenatal diagnosis techniques [71, 72].

Most often the only hope for biological paternity in KS couples is testicular sperm extraction (TESE) combined with intracytoplasmic sperm injection. The initial success rate of TESE in adult 47,XXY males in small series have been $40-50 \%$ [3], and later a rate as high as $70 \%$ has been achieved [69]. Live birth rates of $20-46 \%$ have been reported once sperm are obtained $[69,71]$. In the KS male, the only predictive factor for successful sperm recovery seems to be the testicular histopathology [73], but even with no sperm in a biopsy specimen, TESE has proven successful $[69,74]$. Neither testicular ultrasonography, extensive chromosome analysis, degree of virilization, testicular volume, nor serum testosterone, $\mathrm{FSH}, \mathrm{LH}$, or inhibin B level is predictive for outcome of TESE [73, 74]; even patients with unmeasurable inhibin $B$ levels have undergone successful TESE [75].

In boys with KS, the fact that the number of adult dark spermatogonia - of fundamental importance for development of male fertility [49] - is markedly reduced indicates a severely impaired fertility potential even before puberty [19]. Cryopreservation of semen samples containing very low numbers of spermatozoa from KS boys in early puberty is possible and should be offered to appropriate patients before the start of testosterone supplementation. The expected success rate is, however, exceedingly low, since onset of puberty initiates a marked acceleration in germ cell depletion, and one must also take into account the limited ability of boys to provide semen samples during early puberty. Another option would be TESE, if the biopsy sample contains haploid germ cells.
The possible future use for infertility treatments of cryopreserved testicular samples containing spermatogonia but not more mature germ cells would require in vitro maturation of spermatogonia into mature spermatozoa or at least into late/elongated spermatids. Recent studies indicate that human testicular tissue can be cultured for at least up to 3 weeks without essential loss of spermatogonia $[76,77]$. Early results also suggest that meiosis and spermatogenesis may resume under culture conditions, yielding normal spermatids with some fertilization potential [77]. However, at present this option for fertility preservation in boys before spermarche remains entirely experimental.

\section{Concluding Remarks}

Placebo-controlled studies are vital to determine the role of hypogonadism in aggravating the 47,XXY phenotype, because all the characteristics of the KS phenotype cannot be ascribed to the relative androgen deficiency; other factors such as the excess of $\mathrm{X}$ chromosome genes probably also have some impact. Whether the defect in the 47,XXY testis is intrinsic to germ cells or is due to inability of the Sertoli cells to support normal germ cell development remains unknown. Furthermore, we do not know whether the Leydig cell failure is a consequence of germ cell depletion and Sertoli cell injury or is intrinsic to Leydig cells. Molecular mechanisms behind the testicular degeneration in KS have remained a mystery and require further elucidation.

\section{References}

1 Klinefelter HF, Reifenstein EC, Albright F: Syndrome characterized by gynecomastia, aspermatogenesis without aleydigism, and increased excretion of follicle-stimulating hormone. J Clin Endocrinol 1942;2:615627.

-2 Jacobs PA, Strong JA: A case of human intersexuality having a possible XXY sex-determining mechanism. Nature 1959;183:302303.

- 3 Lanfranco F, Kamischke A, Zitzmann M, Nieschlag E: Klinefelter's syndrome. Lancet 2004;364:273-283.

-4 Bojesen A, Juul S, Gravholt CH: Prenatal and postnatal prevalence of Klinefelter syndrome: a national registry study. J Clin Endocrinol Metab 2003;88:622-626.
5 Van Assche E, Bonduelle M, Tournaye H, Joris H, Verheyen G, Devroey P, Van Steirteghem A, Liebaers I: Cytogenetics of infertile men. Hum Reprod 1996;11(suppl 4):1-26.

-6 Abramsky L, Chapple J: 47,XXY (Klinefelter syndrome) and 47,XYY: estimated rates of and indication for postnatal diagnosis with implications for prenatal counselling. Prenat Diagn 1997;17:363-368.

7 Simpson JL, de la Cruz F, Swerdloff RS, Samango-Sprouse C, Skakkebaek NE, Graham JM Jr, Hassold T, Aylstock M, Meyer-Bahlburg HF, Willard HF, Hall JG, Salameh W, Boone K, Staessen C, Geschwind D, Giedd J, Dobs AS, Rogol A, Brinton B, Paulsen CA: Klinefelter syndrome: expanding the phenotype and identifying new research directions. Genet Med 2003;5:460-468.
8 Ratcliffe SG: The sexual development of boys with the chromosome constitution 47,XXY (Klinefelter's syndrome). Clin Endocrinol Metab 1982;11:703-716.

$\checkmark 9$ Ross JL, Samango-Sprouse C, Lahlou N, Kowal K, Elder FF, Zinn A: Early androgen deficiency in infants and young boys with 47,XXY Klinefelter syndrome. Horm Res 2005;64:39-45.

10 Visootsak J, Aylstock M, Graham JM Jr: Klinefelter syndrome and its variants: an update and review for the primary pediatrician. Clin Pediatr (Phila) 2001;40:639-651.

11 Ratcliffe S: Long-term outcome in children of sex chromosome abnormalities. Arch Dis Child 1999;80:192-195. 
12 Stewart DA, Bailey JD, Netley CT, Rovet J, Park E: Growth and development from early to midadolescence of children with $\mathrm{X}$ and $\mathrm{Y}$ chromosome aneuploidy: the Toronto Study. Birth Defects Orig Artic Ser 1986;22:119182.

13 Robinson A, Bender BG, Borelli JB, Puck MH, Salbenblatt JA, Winter JS: Sex chromosomal aneuploidy: prospective and longitudinal studies. Birth Defects Orig Artic Ser 1986;22:23-71.

-14 Ratcliffe SG, Read G, Pan H, Fear C, Lindenbaum R, Crossley J: Prenatal testosterone levels in XXY and XYY males. Horm Res 1994;42:106-109.

15 Sorensen K, Nielsen J, Wohlert M, Bennett P, Johnsen SG: Serum testosterone of boys with karyotype 47,XXY (Klinefelter's syndrome) at birth. Lancet 1981;ii:1112-1113.

16 Lahlou N, Fennoy I, Carel JC, Roger M: Inhibin $\mathrm{B}$ and anti-müllerian hormone, but not testosterone levels, are normal in infants with non-mosaic Klinefelter syndrome. J Clin Endocrinol Metab 2004;89:1864-1868.

$\checkmark 17$ Aksglaede L, Petersen JH, Main KM, Skakkebaek NE, Juul A: High normal testosterone levels in infants with non-mosaic Klinefelter's syndrome. Eur J Endocrinol 2007;157: 345-350.

18 Wikström AM, Dunkel L, Wickman S, Norjavaara E, Ankarberg-Lindgren C, Raivio T: Are adolescent boys with Klinefelter syndrome androgen deficient? A longitudinal study of Finnish 47,XXY boys. Pediatr Res 2006;59:854-859.

19 Wikström AM, Raivio T, Hadziselimovic F, Wikström S, Tuuri T, Dunkel L: Klinefelter syndrome in adolescence: onset of puberty is associated with accelerated germ cell depletion. J Clin Endocrinol Metab 2004;89:22632270.

20 Wikström AM, Bay K, Hero M, Andersson AM, Dunkel L: Serum INSL3 levels during puberty in healthy boys and boys with Klinefelter syndrome. J Clin Endocrinol Metab 2006;91:4705-4708.

-21 Salbenblatt JA, Bender BG, Puck MH, Robinson A, Faiman C, Winter JS: Pituitary-gonadal function in Klinefelter syndrome before and during puberty. Pediatr Res 1985;19: 82-86.

-22 Topper E, Dickerman Z, Prager-Lewin R, Kaufman H, Maimon Z, Laron Z: Puberty in 24 patients with Klinefelter syndrome. Eur J Pediatr 1982;139:8-12.

-23 Christiansen P, Andersson AM, Skakkebaek NE: Longitudinal studies of inhibin B levels in boys and young adults with Klinefelter syndrome. J Clin Endocrinol Metab 2003;88: 888-891.

24 Winter JS: Androgen therapy in Klinefelter syndrome during adolescence. Birth Defects Orig Artic Ser 1990;26:235-245.
25 Foresta C, Bettella A, Vinanzi C, Dabrilli P, Meriggiola MC, Garolla A, Ferlin A: Insulinlike factor 3: a novel circulating hormone of testis origin in humans. J Clin Endocrinol Metab 2004;89:5952-5958.

-26 Bay K, Hartung S, Ivell R, Schumacher M Jurgensen D, Jorgensen N, Holm M, Skakkebaek NE, Andersson AM: Insulin-like factor 3 serum levels in 135 normal men and 85 men with testicular disorders: relationship to the luteinizing hormone-testosterone axis. J Clin Endocrinol Metab 2005;90:3410 3418.

27 Ivell R, Bathgate RA: Reproductive biology of the relaxin-like factor (RLF/INSL3). Biol Reprod 2002;67:699-705.

28 Ferlin A, Garolla A, Rigon F, Rasi Caldogno L, Lenzi A, Foresta C: Changes in serum insulin-like factor 3 during normal male puberty. J Clin Endocrinol Metab 2006;91: 3426-3431.

29 Andersson AM, Muller J, Skakkebaek NE: Different roles of prepubertal and postpubertal germ cells and Sertoli cells in the regulation of serum inhibin B levels. J Clin Endocrinol Metab 1998;83:4451-4458.

30 Andersson AM, Juul A, Petersen JH, Muller J, Groome NP, Skakkebaek NE: Serum inhibin B in healthy pubertal and adolescent boys: relation to age, stage of puberty, and follicle-stimulating hormone, luteinizing hormone, testosterone, and estradiol levels. J Clin Endocrinol Metab 1997;82:3976-3981.

- 31 Raivio T, Perheentupa A, McNeilly AS, Groome NP, Anttila R, Siimes MA, Dunkel $\mathrm{L}$ : Biphasic increase in serum inhibin B during puberty: a longitudinal study of healthy Finnish boys. Pediatr Res 1998;44:552-556.

32 Lee MM, Donahoe PK, Hasegawa T, Silverman B, Crist GB, Best S, Hasegawa Y, Noto RA, Schoenfeld D, MacLaughlin DT: Müllerian inhibiting substance in humans: normal levels from infancy to adulthood. J Clin Endocrinol Metab 1996;81:571-576.

-33 Rey R, Lordereau-Richard I, Carel JC, Barbet P, Cate RL, Roger M, Chaussain JL, Josso N: Anti-müllerian hormone and testosterone serum levels are inversely related during normal and precocious pubertal development. J Clin Endocrinol Metab 1993;77: 1220-1226.

34 Al-Attar L, Noel K, Dutertre M, Belville C, Forest MG, Burgoyne PS, Josso N, Rey R: Hormonal and cellular regulation of Sertoli cell anti-müllerian hormone production in the postnatal mouse. J Clin Invest 1997;100: 1335-1343.

35 Ratcliffe SG, Murray L, Teague P: Edinburgh study of growth and development of children with sex chromosome abnormalities. III. Birth Defects Orig Artic Ser 1986;22:73118.

- 36 Illig R, Tolksdorf M, Murset G, Prader A: LH and FSH response to synthetic LH-RH in children and adolescents with Turner's and Klinefelter's syndrome. Helv Paediatr Acta 1975;30:221-231.
37 De Behar BR, Mendilaharzu H, Rivarola MA, Bergada C: Gonadotropin secretion in prepubertal and pubertal primary hypogonadism: response to LHRH. J Clin Endocrinol Metab 1975;41:1070-1075.

38 Smyth CM, Bremner WJ: Klinefelter syndrome. Arch Intern Med 1998;158:13091314.

39 Anawalt BD, Bebb RA, Matsumoto AM, Groome NP, Illingworth PJ, McNeilly AS, Bremner WJ: Serum inhibin B levels reflect Sertoli cell function in normal men and men with testicular dysfunction. J Clin Endocrinol Metab 1996;81:3341-3345.

40 Klingmuller D, Haidl G: Inhibin B in men with normal and disturbed spermatogenesis. Hum Reprod 1997;12:2376-2378.

41 Coerdt W, Rehder H, Gausmann I, Johannisson R, Gropp A: Quantitative histology of human fetal testes in chromosomal disease. Pediatr Pathol 1985;3:245-259.

42 Murken JD, Stengel-Rutkowski S, Walther JU, Westenfelder SR, Remberger KH, Zimmer F: Klinefelter's syndrome in a fetus (letter). Lancet 1974;ii:171.

43 Gustavson KH, Kjessler B, Thoren S: Prenatal diagnosis of an XXY foetal karyotype in a woman with a previous 21-trisomic child. Clin Genet 1978;13:477-480.

-44 Flannery DB, Brown JA, Redwine FO, Winter P, Nance WE: Antenatally detected Klinefelter's syndrome in twins. Acta Genet Med Gemellol (Roma) 1984;33:51-56.

45 Mikamo K, Aguercif M, Hazeghi P, MartinDu Pan R: Chromatin-positive Klinefelter's syndrome. A quantitative analysis of spermatogonial deficiency at 3,4 , and 12 months of age. Fertil Steril 1968;19:731-739.

46 Edlow JB, Shapiro LR, Hsu LY, Hirschhorn K: Neonatal Klinefelter's syndrome. Am J Dis Child 1969;118:788-791.

-47 Muller J, Skakkebaek NE, Ratcliffe SG: Quantified testicular histology in boys with sex chromosome abnormalities. Int J Androl 1995; 18:57-62.

48 Ferguson-Smith MA: The prepubertal testicular lesion in chromatin-positive Klinefelter's syndrome (primary micro-orchidism) as seen in mentally handicapped children. Lancet 1959;i:219-222.

-49 Hadziselimovic F, Herzog B: The importance of both an early orchidopexy and germ cell maturation for fertility. Lancet 2001;358: 1156-1157.

50 Wikström AM, Hoei-Hansen CE, Dunkel L, Rajpert-De Meyts E: Immunoexpression of androgen receptor and nine markers of maturation in the testes of adolescent boys with Klinefelter syndrome: evidence for degeneration of germ cells at the onset of meiosis. J Clin Endocrinol Metab 2007;92:714-719.

-51 Sharpe RM, McKinnell C, Kivlin C, Fisher JS: Proliferation and functional maturation of Sertoli cells, and their relevance to disorders of testis function in adulthood. Reproduction 2003; $125: 769-784$ 
52 Gasc JM, Baulieu EE: Steroid hormone receptors: intracellular distribution. Biol Cell 1986;56:1-6.

53 Gordon DL, Krmpotic E, Thomas W, Gandy HM, Paulsen CA: Pathologic testicular findings in Klinefelter's syndrome. 47,XXY vs. 46,XY-47,XXY. Arch Intern Med 1972;130: $726-729$.

-54 Aksglaede L, Wikström AM, Rajpert-De Meyts E, Dunkel L, Skakkebaek NE, Juul A: Natural history of seminiferous tubule degeneration in Klinefelter syndrome. Hum Reprod Update 2006;12:39-48.

-55 Foresta C, Galeazzi C, Bettella A, Marin P, Rossato M, Garolla A, Ferlin A: Analysis of meiosis in intratesticular germ cells from subjects affected by classic Klinefelter's syndrome. J Clin Endocrinol Metab 1999;84: 3807-3810.

56 Skakkebaek NE: Two types of tubules containing only Sertoli cells in adults with Klinefelter's syndrome. Nature 1969;223: 643-645.

-57 Nistal M, Paniagua R, Abaurrea MA, Santamaria L: Hyperplasia and the immature appearance of Sertoli cells in primary testicular disorders. Hum Pathol 1982;13:3-12.

58 Regadera J, Codesal J, Paniagua R, Gonzalez-Peramato P, Nistal M: Immunohistochemical and quantitative study of interstitial and intratubular Leydig cells in normal men, cryptorchidism, and Klinefelter's syndrome. J Pathol 1991;164:299-306.

-59 Iitsuka Y, Bock A, Nguyen DD, SamangoSprouse CA, Simpson JL, Bischoff FZ: Evi dence of skewed X-chromosome inactivation in 47,XXY and 48,XXYY Klinefelter patients. Am J Med Genet 2001;98:25-31.

60 Wikström AM, Painter JN, Raivio T, Aittomäki K, Dunkel L: Genetic features of the $\mathrm{X}$ chromosome affect pubertal development and testicular degeneration in adolescent boys with Klinefelter syndrome. Clin Endocrinol (Oxf) 2006;65:92-97.
1 Jacobs PA, Hassold TJ, Whittington E, Butler G, Collyer S, Keston M, Lee M: Klinefelter's syndrome: an analysis of the origin of the additional sex chromosome using molecular probes. Ann Hum Genet 1988;52:93-109.

62 Lorda-Sanchez I, Binkert F, Maechler M, Robinson WP, Schinzel AA: Reduced recombination and paternal age effect in Klinefelter syndrome. Hum Genet 1992;89: 524-530.

63 Zinn AR, Ramos P, Elder FF, Kowal K, Samango-Sprouse C, Ross JL: Androgen receptor CAGn repeat length influences phenotype of 47,XXY (Klinefelter) syndrome. J Clin Endocrinol Metab 2005;90:5041-5046.

64 Zitzmann M, Nieschlag E: The CAG repeat polymorphism within the androgen receptor gene and maleness. Int J Androl 2003;26 $76-83$.

65 Zitzmann M, Depenbusch M, Gromoll J, Nieschlag E: X-chromosome inactivation patterns and androgen receptor functionality influence phenotype and social charac teristics as well as pharmacogenetics of testosterone therapy in Klinefelter patients. J Clin Endocrinol Metab 2004;89:6208-6217.

66 Scanlan MJ, Gure AO, Jungbluth AA, Old LJ, Chen YT: Cancer/testis antigens: an expanding family of targets for cancer immunotherapy. Immunol Rev 2002;188:22-32.

67 Wang PJ, McCarrey JR, Yang F, Page DC: An abundance of X-linked genes expressed in spermatogonia. Nat Genet 2001;27:422426.

68 Mroz K, Carrel L, Hunt PA: Germ cell development in the XXY mouse: evidence that X chromosome reactivation is independent of sexual differentiation. Dev Biol 1999;207: 229-238.

69 Schiff JD, Palermo GD, Veeck LL, Goldstein M, Rosenwaks Z, Schlegel PN: Success of testicular sperm injection and intracytoplasmic sperm injection in men with Klinefelter syndrome. J Clin Endocrinol Metab 2005;90: 6263-6267.

70 McLachlan RI, O’Donnell L, Stanton PG, Balourdos G, Frydenberg M, de Kretser DM, Robertson DM: Effects of testosterone plus medroxyprogesterone acetate on semen quality, reproductive hormones, and germ cell populations in normal young men. J Clin Endocrinol Metab 2002;87:546-556.
71 Staessen C, Tournaye H, Van Assche E, Michiels A, Van Landuyt L, Devroey $P$, Liebaers I, Van Steirteghem A: PGD in 47, XXY Klinefelter's syndrome patients. Hum Reprod Update 2003;9:319-330.

72 Denschlag D, Tempfer C, Kunze M, Wolff G, Keck C: Assisted reproductive techniques in patients with Klinefelter syndrome: a critical review. Fertil Steril 2004;82:775-779.

$>73$ Westlander G, Ekerhovd E, Granberg S, Hanson L, Hanson C, Bergh C: Testicular ultrasonography and extended chromosome analysis in men with non-mosaic Klinefelter syndrome: a prospective study of possible predictive factors for successful sperm recovery. Fertil Steril 2001;75:1102-1105.

74 Vernaeve V, Staessen C, Verheyen G, Van Steirteghem A, Devroey P, Tournaye H: Can biological or clinical parameters predict testicular sperm recovery in 47,XXY Klinefelter's syndrome patients? Hum Reprod 2004; 19:1135-1139.

75 Westlander G, Ekerhovd E, Bergh C: Low levels of serum inhibin B do not exclude successful sperm recovery in men with nonmosaic Klinefelter syndrome. Fertil Steril 2003; 79(suppl 3):1680-1682.

76 Larsen HP, Thorup J, Skovgaard LT, Cortes D, Byskov AG: Long-term cultures of testicular biopsies from boys with cryptorchidism: effect of FSH and LH on the number of germ cells. Hum Reprod 2002;17:383-389.

77 Sousa M, Cremades N, Alves C, Silva J, Barros A: Developmental potential of human spermatogenic cells co-cultured with Sertoli cells. Hum Reprod 2002;17:161-172.

78 Ojajärvi P: The Adolescent Finnish Child: A Longitudinal Study of the Anthropometry, Physical Development and Physiological Changes during Puberty. Helsinki, University of Helsinki, 1982.

79 Greulich WW, Pyle SL: Atlas of Skeletal Development of the Hand and Wrist, ed 2. Stanford, Stanford University Press, 1959. 